\title{
Influence of waste marble powder as a replacement of cement on the properties of mortar
}

\section{Influencia de los residuos como un reemplazo de polvo de mármol sobre las propiedades del mortero de cemento}

\section{Kenan Yamanel (Main Author)}

Çimsa Cement Industry and Trade Inc., İstanbul (Turkey)

kenan_yamanel@hotmail.com

Uğur Durak (Corresponding Author)

Erciyes University, Civil Engineering Department, Kayseri (Turkey)

ugurdurak@erciyes.edu.tr

\section{Serhan IIlkentapar}

Erciyes University, Civil Engineering Department, Kayseri (Turkey) serhan@erciyes.edu.tr

\section{İsmail İsa Atabey}

Nevşehir Hacı Bektaş Veli University, Civil Engineering Department, Nevşehir (Turkey) ismailatabey@nevsehir.edu.tr

\section{Okan Karahan}

Erciyes University, Civil Engineering Department, Kayseri (Turkey)

okarahan@erciyes.edu.tr

\section{Cengiz Duran Atiş}

Erciyes University, Civil Engineering Department, Kayseri (Turkey) cdatis@erciyes.edu.tr

Manuscript Code: 1293

Date of Acceptance/Reception: 22.07.2019/08.01.2019

DOI: 10.7764/RDLC.18.2.290

\begin{abstract}
The demand for cement usage increases in the world, currently. It is known that using industrial waste materials in concrete as cement or aggregate replacement as part of waste management as well as conserving natural resources is getting wider. Due to these facts, in this work, an investigation was carried out on the utilization of waste marble powders as cement replacement mineral materials. In this context, marble powder replaced cement at $5 \%, 10 \%, 15 \%$ and $20 \%$ in mass basis, and mortars were produced. In mortar mixtures, water-binder ratio was chosen as 0.5 , and sand-binder ratio was taken as 3. Workability of fresh mortar was measured. Unit weight, water absorption, and porosity, compressive and flexural strengths, abrasion, carbonation and drying shrinkage measurements testing were carried out on hardened mortar specimens. Influence of elevated temperature on hardened mortar mixture was also investigated. As a result of laboratory study, it is concluded that replacing marble powder with cement result with a favourable contribution to workability of fresh mortar, as well as resistance to elevated temperature. It also reduced drying shrinkage of mortar in comparison to reference mortar made without marble powder. However, it influenced water absorption, abrasion, and carbonation resistance of mortar, unfavourably. For short term curing duration, replacement of marble powder with cement reduced compressive strength insignificantly for $5 \%$ and $10 \%$ marble powder replacement, but, reduced it significantly for $15 \%$ and $20 \%$. However, at long term curing at 90 days, the difference between strength of reference mortar and marble containing mortar was diminished, particularly for mortar containing $5 \%$ and $10 \%$ marble powder.
\end{abstract}

Keywords: Mortar, waste marble powder, cement replacement, durability.

\section{Resumen}

La demanda de uso de cemento actualmente aumenta en el mundo. Se sabe que el uso de materiales de residuos industriales en el hormigón como reemplazo de cemento o agregado como parte de la gestión de residuos, así como la conservación de los recursos naturales, se está haciendo cada vez más amplio. Debido a estos hechos, en este trabajo, se realizó una investigación sobre la utilización de residuos de polvos de mármol como materiales minerales de reemplazo de cemento. En este contexto, el cemento fue reemplazado con polvo de mármol en el 5 , 10 , 15 y $20 \%$ en base a la masa, y se produjeron morteros. En mezclas de mortero, la proporción de aglomerante de agua se eligió como 0.5, y la relación de aglomerante de arena se tomó como 3. Se midió la trabajabilidad del mortero fresco. Se realizaron muestras de mortero endurecido, midiendo peso por unidad, absorción de agua y porosidad, resistencia a la compresión y flexión, abrasión, carbonatación y contracción por secado. También se investigó la influencia de la temperatura elevada en la mezcla de mortero endurecido. Como resultado de un estudio de laboratorio, se concluye que la sustitución del polvo de mármol por el cemento da como resultado una contribución favorable a la trabajabilidad del mortero fresco, así como a la resistencia a 

mármol. Sin embargo, influyó desfavorablemente en la absorción de agua, abrasión y resistencia a la carbonatación del mortero. Para la duración del curado a corto plazo, el reemplazo del polvo de mármol con cemento redujo la resistencia a la compresión de manera insignificante para el $5 \%$ y el $10 \%$ de reemplazo del polvo de mármol, pero lo redujo significativamente del $15 \%$ y $20 \%$. Sin embargo, en el curado a largo plazo a los 90 días, la diferencia entre la resistencia del mortero de referencia y el mármol que contenía el mortero disminuyó, especialmente para el mortero que contenía polvo de mármol al $5 \%$ y al $10 \%$.

It is known that using industrial waste in concrete or mortar as part of waste management is getting wider (Uysal, Akyuncu, Tanyildizi, Sumer, \& Yildirim, 2018). Marble industry results with waste marble powder which should be disposed of. Disposal of the marble powder resulting from the marble industry is one of the environmental concern and problems worldwide today. Marble powder results from processing plants sawing and polishing of marble blocks (Talah, Kharchi, \& Chaid, 2015).

It is reported by Alyamac, Ghafari, \& Ince (2017), that quantity of waste marble powder reaches more than millions of tons in Turkey. It was nearly one million tons in Spain and more than two million tons in Egypt.

These waste marble powder, generally, was dumped into open areas near the quarry site and as a result, it causes unacceptable environmental impacts. Therefore, utilization of marble powder waste in concrete or cement paste will provide an opportunity to obtain environmental and economic gains from a sustainable development point of view (Toubal Seghir, Mellas, Sadowski, \& Żak, 2018).

A literature review on the usage of marble powder in concrete or mortar was presented with the succeeding paragraph.

Khyaliya, Kabeer, \& Vyas (2017), carried out a laboratory study to evaluate usage of marble waste as a fine aggregate replacement in mortar mixtures. They reported that using marble waste from $25 \%$ to $50 \%$ could give a benefit in terms of water requirement and better mechanical properties compared to control cement mortar mixtures. Marble waste containing mortar showed good performance in both aggressive and non-aggressive environments. Drying shrinkage of marble waste containing mortar mixtures was found to be in the order of cement mortar mixture shrinkage.

Corinaldesi, Moriconi, \& Naik (2010), used marble waste as mineral addition in mortar. Marble waste was obtained from sawing and shaping process of marble. Its Blaine-fineness was about $1500 \mathrm{~m}^{2} / \mathrm{kg}$ and considered very high value. They replaced marble powder with cement or sand in mass basis, separately. They concluded that $10 \%$ replacement was found to be an optimal value since it provided similar workability and strength properties to control cement mortar.

Ergün (2011), worked on the usability of diatomite and waste marble powder as a partial replacement of cement in terms of mechanical properties of concrete. Based on his laboratory experiment, he suggested that diatomite and waste marble powder could be utilized up to $10 \%$ separately or together as a replacement of Portland cement in the production of concrete, respectively. He suggested using superplastizing admixture in these concrete mixtures.

Hebhoub, Aoun, Belachia, Houari, \& Ghorbel (2011), carried out a laboratory investigation on using waste marble aggregates in concrete. In the experimental investigation, three different approaches were made; one was sand substitution with waste marble, second was gravel substitution with waste marble and third was both sand and gravel substitution together. Constant water-cement ratio was chosen. The results proved that up to $75 \%$ replacement of waste marble is possible since waste marble containing concretes gained compressive strength which conforms with the concrete production standards.

Aliabdo, Abd Elmoaty, \& Auda (2014), made a laboratory study to investigate utilization of waste marble dust in cement and concrete. Two replacement methods were employed in the work, cement replacement and sand replacement with waste marble powder. In the study, marble dust replaced cement and sand up to $15 \%$ replacement ratio, separately. They used two water-binder ratios, 0.4 and 0.5 . They concluded that, in general, inclusion of marble dust in concrete production as cement replacement or sand replacement, gradually improved mechanical and physical properties of concrete, particularly at the lower water-binder ratio. They observed that marble dust exhibited filler effect in concrete and had no significant role in the hydration process. However, concrete made with marble dust as sand replacement gained better performance compared to concrete made with marble dust as cement replacement. 
Vardhan, Goyal, Siddique, \& Singh (2015), reported an investigation results regarding usage of marble powder as cement replacement. The setting behaviour, soundness and flowability properties of paste made with partial replacement of marble powder with cement were studied. Strength development and microstructural properties were also examined. They reported that $10 \%$ replacement of marble powder with cement could be utilized since it did not show detrimental effects on technical characteristic of the mix. They also concluded that higher replacement than $10 \%$ value leads to delay in hydration, causes higher porosity and lower compressive strength. Marble powder did not adversely influence the expansion and setting characteristic of the mix produced.

Tekin (2016), carried out an interesting study on utilizing waste marble in the production of geopolymer composite pastes. They activated geopolymer composite pastes with $1 \mathrm{M}, 5 \mathrm{M}$, and $10 \mathrm{M} \mathrm{NaOH}$ activator. Curing was made at $20^{\circ} \mathrm{C}$, $45^{\circ} \mathrm{C}$, and $75^{\circ} \mathrm{C}$ degree for 24 hours in the oven. Strengths were measured at 2, 3, 7, 28 and $90 \mathrm{~d}$ after wet and dry curing. The highest compressive strength value reported was $46 \mathrm{MPa}$.

Singh, Srivastava, \& Bhunia (2017), utilized waste marble slurry in concrete as cement replacement. They evaluated effects of marble slurry on the fresh and hardened properties of concrete. They reported that the mechanical properties of concrete enhanced with incorporation of dried marble slurry for up to $15 \%$ replacement. Marble slurry showed filler effect which gave concrete a denser and even structure. Drying shrinkage was found to decrease and strength of mortar improved for a certain percentage replacement.

Kabeer \& Vyas (2018), replaced marble powder with fine aggregate in mortars. Four different mortar mixtures prepared to observe the influence of marble powder on fresh and hardened properties of mixture. They concluded that due to thixotropic property of marble powder, its replacement with river sand result with a reduction in water amount of the mortar mixture. Reduced water content and marble powders' seed effect accelerated hydration of $C_{3} S$, and its formation of calcium carboaluminates with $\mathrm{C}_{3} \mathrm{~A}$ has led to the formation of a denser microstructure. This has considerably improved the mechanical performance of the mortars. Mortar made with $60 \%$ replacement of marble powder as sand replacement gained equivalent or comparable compressive strength to control cement mortar mixture. Drying shrinkage was found to be in the same order with drying shrinkage of control cement mortar. Water absorption and porosity values were higher than corresponding control cement mortar. They concluded that $20 \%$ replacement of marble powder as sand replacement could enable considerable saving of river sand in construction projects. It would also help waste disposal problems due to process of marble dimension stone manufacturing.

Utilization of marble powder as cement replacement in construction materials did not take adequate attention; therefore, more study on the subject may attract using marble powder in concrete and mortar which could also help for conservation of natural resources. In the context of this study, marble powder obtained from marble processing industry was replaced with cement and marble powder containing mortars were produced. Some engineering properties including workability of fresh mortar, unit weight, water absorption, and porosity, compressive and flexural strengths, abrasion, carbonation and drying shrinkage of hardened mortar containing marble powder were measured. Influence of elevated temperature on hardened mortar containing marble powder mixture was also investigated (Yamanel, 2015)

Materials and methods

\section{Cement}

Portland cement (PC) CEM I 42.5 R was used in all mixes. It was supplied from Kahramanmaras Cement Factory. Specific gravity of the cement used was $3.17 \mathrm{~g} / \mathrm{cm}^{3}$. Initial and final setting times of the cement were 200 and 260 minutes, respectively. Its Blaine specific surface area was $3750 \mathrm{~cm}^{2} / \mathrm{g}$. Chemical oxide compositions of cement are given in Table 1.

\begin{tabular}{lcccccccc}
\multicolumn{10}{c}{ Table 1. Oxide composition of cement (\%) (Obtained from Kahramanmaras Cement Factory) } \\
Oxide & $\mathrm{CaO}$ & $\mathrm{Al}_{2} \mathrm{O}_{3}$ & $\mathrm{Fe}_{2} \mathrm{O}_{3}$ & $\mathrm{SiO}_{2}$ & $\mathrm{MgO}$ & $\mathrm{SO}_{3}$ & $\begin{array}{c}\mathrm{Na}_{2} \mathrm{O}+ \\
0.65 \mathrm{~K}_{2} \mathrm{O}\end{array}$ & $\begin{array}{c}\text { Free } \\
\mathrm{CaO}\end{array}$ \\
\hline Cement & 62.9 & 5.81 & 2.61 & 18.8 & 1.29 & 2.74 & 0.74 & 0.7 \\
\hline
\end{tabular}




\section{Marble powder}

Waste marble powder was used in this research. It is taken from Çevikler Marbles company in Kayseri city of Turkey and unit weight of waste marble powder is $2,34 \mathrm{~g} / \mathrm{cm}^{3}$. Before using marble powder in mortar mixtures, it was sieved from 63 microns sieve and dried. Marble powders' chemical oxide compositions determined in Erciyes University laboratory are given in Table 2.

Table 2. Oxide composition of marble powder (\%) (Yamanel, 2015).

\begin{tabular}{lcccccccccccc}
\hline Oxide & $\mathrm{CaO}$ & $\mathrm{Al}_{2} \mathrm{O}_{3}$ & $\mathrm{Fe}_{2} \mathrm{O}_{3}$ & $\mathrm{SiO}_{2}$ & $\mathrm{MgO}$ & $\mathrm{SO}_{3}$ & $\mathrm{SrO}$ & $\mathrm{Na}_{2} \mathrm{O}$ & $\mathrm{BaO}$ & \multirow{2}{*}{$\mathrm{ZnO}$} & $\mathrm{K}_{2} \mathrm{O}$ & $\mathrm{MnO}$ \\
\hline Marble powder & 53.06 & 0.2 & 1.45 & 0.66 & 0.45 & 0.24 & 0.12 & 0.09 & 0.03 & 0.02 & 0.02 & 0.02 \\
\hline
\end{tabular}

\section{Sand}

Natural river sand was employed in the investigation. Water absorption value of sand was $2.18 \%$ and its relative density at saturated surface dry (SSD) condition was 2.5. Sieve analysis of natural river sand was presented in Table 3.

\begin{tabular}{lccccccc}
\hline \multicolumn{1}{c}{ Table 3. Grading of sand (Yamanel, 2015) } \\
\hline Sieve Size $(\mathrm{mm})$ & 0.063 & 0.15 & 0.25 & 0.50 & 1.0 & 2.0 & 4.0 \\
\hline Remaining on sieve (\%) & 0.5 & 3.5 & 18.6 & 29.7 & 18.6 & 3.5 & 0 \\
\hline
\end{tabular}

\section{Mortar mixture proportions and sample preparation}

All mortar specimens were cast at a sand-binder ratio of 3 with 0.5 water-binder ratio. Waste marble replacement ratios used were selected as $0 \%, 5 \%, 10 \%$, and $20 \%$ of mass of cement. Mix proportions of the mortars for a three-cell mould

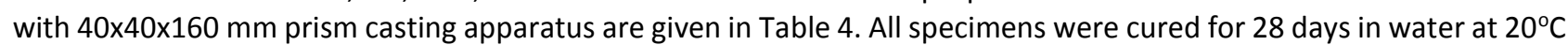
temperature, before testing mechanical and durability related properties of specimens.

\begin{tabular}{ccccc}
\multicolumn{5}{c}{ Table 4. Mixture proportions of mortar (Yamanel, 2015). } \\
\hline Name of & Cement & Marble & Sand & Water \\
specimens & $\mathrm{g}$ & $\mathrm{g}$ & $\mathrm{g}$ & $\mathrm{g}$ \\
\hline M-0 & 450.0 & 0.0 & 1350 & 225 \\
M-5 & 427.5 & 22.5 & 1350 & 225 \\
M-10 & 405.0 & 45.0 & 1350 & 225 \\
M-15 & 382.5 & 67.5 & 1350 & 225 \\
M-20 & 360.0 & 90.0 & 1350 & 225 \\
\hline
\end{tabular}

Results and discussion

\section{Unit weight}

The unit weight was determined after 28 days of water curing according to ASTM C642-13 (ASTM C 642-13, 2013). Unit weights of mortars were presented in Table 5 . Table 5 shows that dry unit weight values were decreased for the specimens having waste marble powder as a partial mass replacement with cement; the higher replacement caused higher reduction in unit weight. This is explained and attributed to differences between specific gravity of cement and marble powder, while unit weight of waste marble powder is $2.34 \mathrm{~g} / \mathrm{cm}^{3}$, unit weight of cement is $3.17 \mathrm{~g} / \mathrm{cm}^{3}$. Higher replacement of higher specific gravity materials with lower specific gravity material means the lower weight of final product. This finding is found to agree with published results of Toubal Seghir et al. (2018).

Table 5. Unit Weight $\left(\mathrm{g} / \mathrm{cm}^{3}\right)$ (Yamanel, 2015).

\begin{tabular}{cc}
\hline Mix no. & Dry Unit Weight \\
\hline M-0 & 2.03 \\
M-5 & 2.02 \\
$M-10$ & 2.02 \\
$M-15$ & 2.00 \\
$M-20$ & 1.99 \\
\hline
\end{tabular}




\section{Flow test}

The flow test for mortar mixture was conducted according to TS EN 1015-3 (TS EN 1015-3, 2000). Flow table tests results, obtained from mortar mixtures are presented in Figure 1. It is seen from Figure 1 that flow values of mortars increased with the addition of waste marble powder in general. This result can be attributed to difference between specific gravities of two materials. Specific gravity of Portland cement $\left(3.17 \mathrm{~g} / \mathrm{cm}^{3}\right)$ is heavier than specific gravity of waste marble $\left(2.34 \mathrm{~g} / \mathrm{cm}^{3}\right)$. Moreover, replacement of marble with cement is made on mass basis. This means that same weight marble replaced with cement has more volume than Portland cement has; this increases the amount of total paste volume in mortar mixtures resulting in higher workability for mortar. The improvement of using marble powder on workability can be helpful in reduction of quantity of water used in the mixture, thus, utilizing lower water-binder ratio is possible.

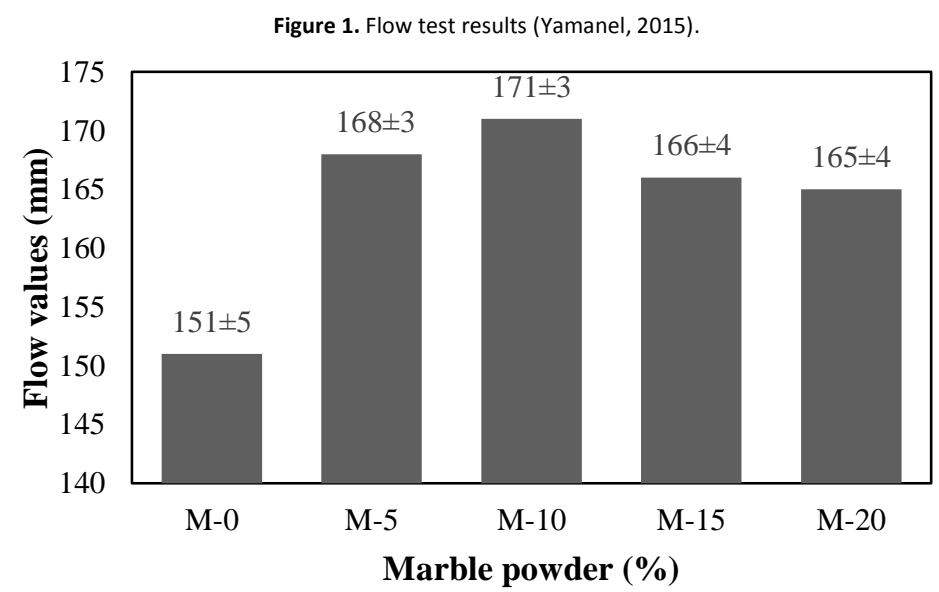

\section{Water absorption and porosity of mortar}

Water absorption and porosity testing results according to ASTM C642 (ASTM C 642-13, 2013) are provided from three specimens for each mixture and presented in Fig. 2 and 3 as average values, respectively. Standard deviation for each water absorption and porosity results data point is calculated and average standard deviations are found to be in the order of 5\%. When Fig. 2 and 3 are closely observed, water absorption value data show that an increase in curing time reduces the amount of absorbed water or becomes stabilized. Similarly, it also reduces porosity value of mortars. This could be attributed to hydration mechanism of cement in mixtures; the more hydration provides more CSH gel and reduces pore volume in the paste. However, using marble powder instead of cement as partial replacement caused an increase in amount of water absorbed as well as porosity of mortar. Increasing the replacement ratio of waste marble causes increase in water absorption value as well as porosity of mortar. This can be attributed to inert nature of waste marble which does not have hydration property with water. Replacing waste marble does not contribute to hydration, thus more replacement of waste marble powder causes less amount of cement meaning less hydration product in mortar mixture. Also, increasing marble content increases the water-cement ratio. This increases the porosity and hence the water absorption capacity.

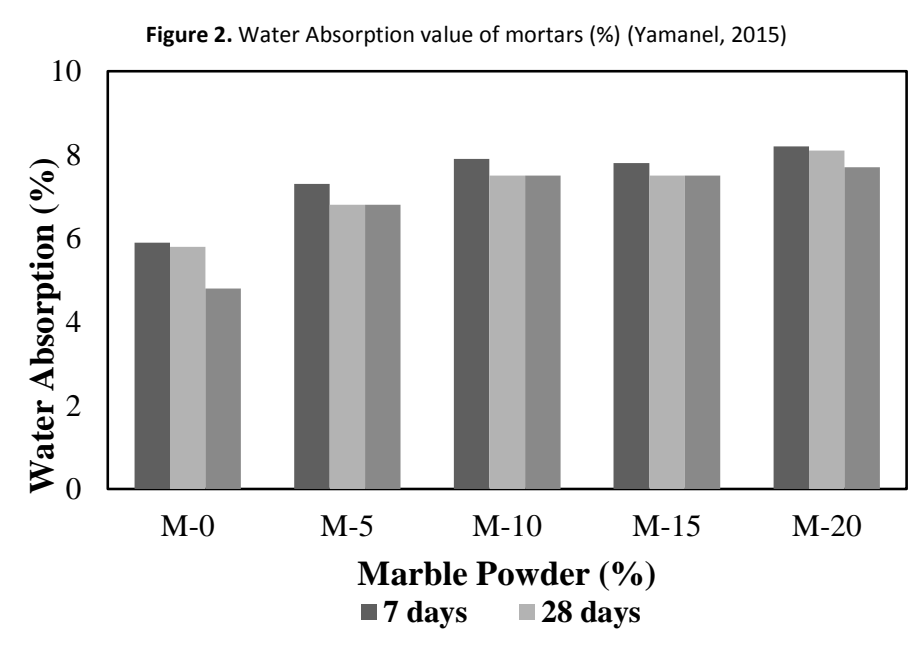




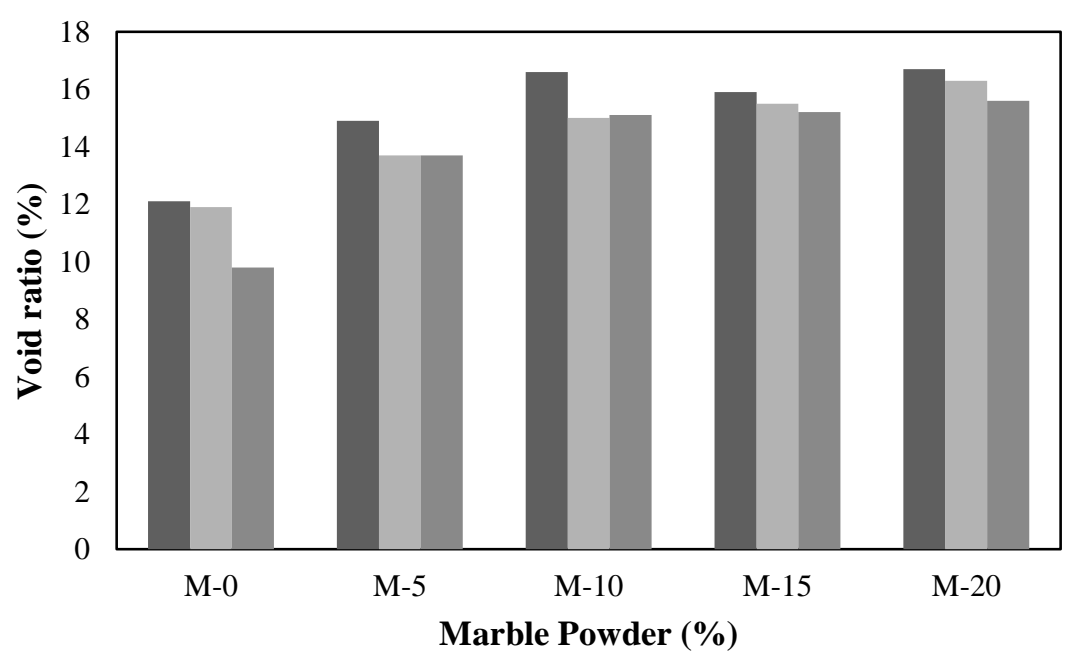

$\square$ days $\quad 28$ days $\square 0$ days

\section{Compressive strength}

Compressive strength measurement obtained using six pieces of the prismatic specimens according to TS EN 1015-11 (TS EN 1015-11, 2000), the results of specimens are given in Table 6. Standard deviation for each compressive strength results data point is determined and average standard deviations are found to be in the order of $4 \%$. As seen in Table 6 , the sample produced with $5 \%$ marble powder gives the highest strength result. Also, it is seen from Table 6 that compressive strengths are improving when curing time increases. The improvement can be explained by the reaction between water and cement particles called hydration of cement. Mortar made with $10 \%$ marble powder gained lower compressive strength than control cement mortar; however, the difference is insignificant. The differences between compressive strength of control mortar and marble containing mortar in percent were 1.1\%, 7.6\%, 12\%, 19\% reduction for $5 \%, 10 \%, 15 \%$, and $20 \%$ replacement ratio at 28 days, respectively. However, they are $1.4 \%$ increase, $3.3 \%, 9.0 \%$, $11 \%$ reduction for the same mortars, respectively at 90 days curing time. The percent reductions in mortar compressive strength at 28 days were lower than the replacement ratio of marble powder, 5\%, 10\%, 15\% and 20\% (which mean reduction in amount of cement). Similarly, percent reductions in mortar compressive strength at 90 days were significantly lower than the replacement ratio of marble powder, 5\%, 10\%, $15 \%$ and $20 \%$. The reductions in mortar compressive strength at 90 days shows that the difference between control cement mortar strength and marble containing mortar decreases for longer curing time. Based on above observation it was concluded that utilization of marble powder as cement replacement causes reduction in compressive strength of mixtures, similar conclusion was also made by Toubal Seghir et al. (2018).

Considering the fact that marble powders are inert and do not hydrate, therefore, compressive strength of all mortar can be normalized by amount of cement in the mixture. This normalization was carried out using replacement ratios of marble, and then normalized compressive strengths were calculated and presented in Table 6. (For example, to find the normalization of the use of 5\% waste marble powder at 7 days, the available value (43.2) was divided by 0.95 and 45.5 was obtained). Normalized compressive strengths were presented in parenthesis. Normalisation showed that compressive strength of marble containing mortars were higher than the compressive strength of control cement mortar. It was commented that although marble does not have pozzolanic property, it helps to improve compressive strength of mortar. This could be explained by the absorption of water by marble powder during preparing fresh mortar, absorbed water does not involve with cement then water-cement ratio of mortar mixture might be reduced relatively, and helping improvement in compressive strength. Also, absorbed water by marble powder helps the internal curing of mortar in long term curing duration and results with improvement in compressive strength. In addition, reduced water content and marble powders' seed effect may accelerate hydration of $\mathrm{C}_{3} \mathrm{~S}$, and its formation of calcium carboaluminates with $C_{3} A$, and caused to the formation of a denser microstructure as explained by Kabeer \& Vyas, (2018). 
Table 6. Compressive strengths of mortar (MPa) (Yamanel, 2015).

\begin{tabular}{cccc}
\hline Mix no & 7 days & 28 days & 90 days \\
\hline M-0 & $45.3(45.3)$ & $52.7(52.7)$ & $55.5(55.5)$ \\
M-5 & $43.2(45.5)$ & $52.1(54.9)$ & $56.3(59.3)$ \\
M-10 & $41.8(46.4)$ & $48.7(54.1)$ & $53.7(59.6)$ \\
M-15 & $38.9(45.8)$ & $46.3(54.5)$ & $50.5(59.4)$ \\
M-20 & $36.5(45.6)$ & $42.8(53.5)$ & $49.1(61.3)$ \\
\hline
\end{tabular}

\section{Flexural strength}

Flexural strength values of control cement mortar and marble powder containing mortars obtained using three prismatic specimens for each mixture according to TS EN 1015-11 (TS EN 1015-11, 2000) are given in Table 7 as average values. Standard deviation for each flexural strength results data point is determined and average standard deviations are found to be in the order of $6 \%$. While curing time increases from 7 days to 90 days, flexural strength of all mortar increased due to hydration of cement particles with water. On the other hand, as increasing replacement ratio of marble powder with cement reduced flexural strength of marble powder containing mortar in comparison to control cement flexural strength. However, reduction in the flexural strength was lower than the replacement ratio of marble powder. Flexural strength of mortar containing $5 \%$ and $10 \%$ marble powder can be assumed equivalent to cement mortar flexural strength at 28 days and 90 days. Even $15 \%$ of marble powder containing mortar showed equivalent flexural strength at 90 days. The explanation made for the influence of marble powder on the compressive strength development of mortar is valid for development and influence on the flexural strength of marble powder containing mortar. Normalized flexural strength by amount of cement was also presented in Table 9. Normalization of flexural strength showed that all normalized strengths were found to be equivalent or higher than that of control cement mortar strength.

\begin{tabular}{cccc}
\multicolumn{4}{c}{ Table 7. Flexural strengths (MPa) (Yamanel, 2015). } \\
\hline Mix no & 7 days & 28 days & 90 days \\
\hline M-0 & $8.2(8.2)$ & $8.6(8.6)$ & $9.7(9.7)$ \\
M-5 & $7.8(8.2)$ & $8.6(9.1)$ & $9.6(10.1)$ \\
M-10 & $7.2(8.0)$ & $8.0(8.9)$ & $9.5(10.5)$ \\
M-15 & $7.0(8.2)$ & $7.7(9.1)$ & $9.3(10.9)$ \\
M-20 & $6.6(8.3)$ & $7.2(9.0)$ & $8.9(11.1)$ \\
\hline
\end{tabular}

\section{Abrasion}

Resistance to abrasive forces of mortar samples was determined by applying abrasion testing to the cubic samples with a side $71 \mathrm{~mm}$ size on abrasion device (Böhme). Abrasion test was carried out, using three specimens for each mixture, according to TS 2824 EN 1338 (TS 2824 EN 1338, 2005). In the experiment, $20 \mathrm{~g}$ of artificial corundum was spread as a standard abrasive on the friction path of sample, then the device was switched on. During the test, the sample was subjected to a vertical weight force of $294 \mathrm{~N}$. The abrasion disc automatically stops after 22 cycles. Sample was turned $90^{\circ}$ clockwise on other face and a new abrasive powder was spread. Every time the disc and contact surface are cleaned. In this way, the second, third and fourth surfaces are also abraded and the first stage is completed after a total of 88 cycles, 4 periods. In the study, 352 cycles were applied to each sample in 16 periods. At the end of the 16th period, the weights of the samples were taken. Density of the samples was calculated using the initial weight and volume of the sample. The difference between the initial weight and last weight taken after the experiment was calculated as weight loss, then, volume loss of sample determined by dividing weight loss with density. Volume loss was considered as the abrasion of the sample. Abrasion testing measurements were presented in Table 8, as average value of three specimens. Standard deviation for each abrasion test results data point is determined and average standard deviations are found to be in the order of $4 \%$. Influence of curing time on abrasion of samples can be seen in Table 8 . As curing time increases abrasion of all mortar samples reduces due to developing hydration product of cement which decrease porosity as well as increase strength properties. However, replacement of marble powder with cement reduced abrasion resistance 
meaning increased abrasion value of sample in comparison to control cement mortar. The higher replacement ratio result with higher abrasion value. This is found to be parallel to result of Koçyiğit (2016).

Higher abrasion value of marble containing mortar versus control cement mortar can be explained by the nature of marble itself. It is known that hardness of marble is lower than siliceous materials. Replacing cement particles with somewhat softer materials might result with higher abrasion.

\begin{tabular}{cccc}
\multicolumn{4}{c}{ Table 8. Volume Loss $\left(\mathrm{mm}^{3} / 5,000 \mathrm{~mm}^{2}\right)($ Yamanel, 2015). } \\
\hline Mix no & 7 days & 28 days & 90 days \\
\hline M-0 & 10,207 & 9,241 & 8,545 \\
M-5 & 13,894 & 13,071 & 11,914 \\
M-10 & 14,213 & 13,828 & 13,434 \\
M-15 & 15,736 & 15,108 & 14,798 \\
M-20 & 17,902 & 17,446 & 17,102 \\
\hline
\end{tabular}

\section{Carbonation}

Carbonation occurs when $\mathrm{CO}_{2}$ gas in the air penetrates the mortar sample. The samples used in the experiment were not water cured to allow the $\mathrm{CO}_{2}$ gas to penetrate the sample. The samples were stored in curing chamber with $50 \%$ relative humidity at $20^{\circ} \mathrm{C}$, for 210 days. The effect of marble powder on carbonation depth is presented in Figure 4 which clearly shows that using more marble powder content increased the carbonation depth. This is related with porosity of mortar, higher marble powder content in mortar already caused higher porosity that causes higher ingress of $\mathrm{CO}_{2}$ into the sample which forms carbonation by reacting with portlandite. The increase of porosity allows deeper $\mathrm{CO}_{2}$ penetration in mortar.

Figure 4. Carbonation depths of mortars (mm) (Yamanel, 2015).

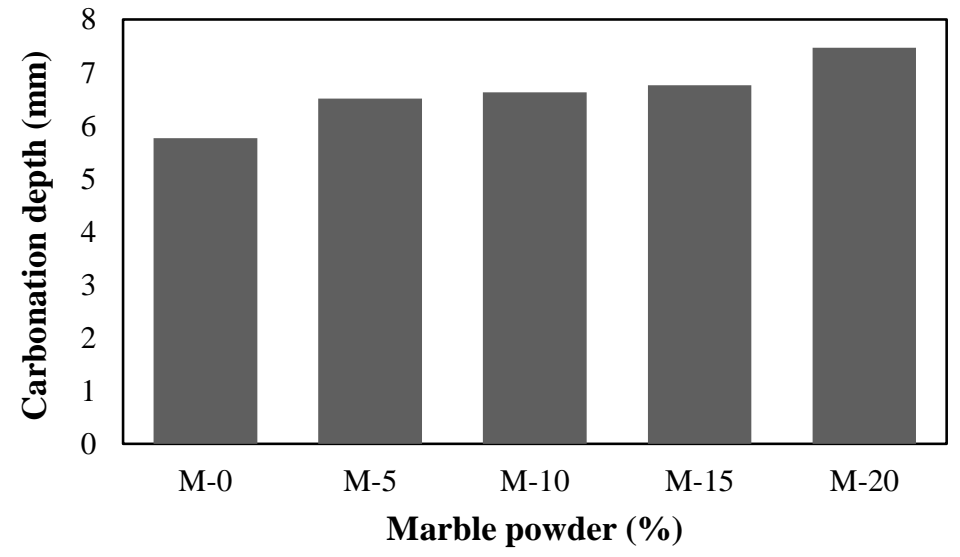

\section{Fire resistance results}

Elevated temperature tests were conducted on the $40 \times 40 \times 160 \mathrm{~mm}$ prismatic samples. Specimens were exposed to 300 ${ }^{\circ} \mathrm{C}, 600^{\circ} \mathrm{C}$, and $900{ }^{\circ} \mathrm{C}$ temperatures. Temperature of oven increased $5^{\circ} \mathrm{C}$ degree at a minute till testing temperature. At target exposure temperature, specimens were exposed to target temperature for one hour, and then oven was stopped. After exposure to high temperature, the specimens were cooled in the furnace to cool down to room temperature. After cooling period, three specimens were subjected to compressive and flexural tests. The flexural test results and compressive test results and are presented in Table 9 and Table 10, respectively.

In Table 9 and Table 10 flexural and compressive strength of mortar after elevated temperature were presented as a ratio to the strength of mortar before exposure to elevated temperature at $20^{\circ} \mathrm{C}$, in parenthesis. 
Table 9. Flexural test results after high temperature (MPa) (\%) (Yamanel, 2015)

\begin{tabular}{ccccc}
\hline Mix no & $20^{\circ} \mathrm{C}$ & $300{ }^{\circ} \mathrm{C} / 20^{\circ} \mathrm{C}$ & $600{ }^{\circ} \mathrm{C} / 20^{\circ} \mathrm{C}$ & $900{ }^{\circ} \mathrm{C} / 20^{\circ} \mathrm{C}$ \\
\hline $\mathrm{M}-0$ & 8.60 & $8.0(0.93)$ & $4.5(0.52)$ & $1.3(0.15)$ \\
$\mathrm{M}-5$ & 8.60 & $8.1(0.94)$ & $3.5(0.41)$ & $1.6(0.19)$ \\
$\mathrm{M}-10$ & 8.00 & $7.7(0.96)$ & $4.1(0.51)$ & $1.1(0.14)$ \\
$\mathrm{M}-15$ & 7.70 & $7.8(1.01)$ & $3.8(0.49)$ & $1.4(0.18)$ \\
$\mathrm{M}-20$ & 7.20 & $7.0(0.97)$ & $4.1(0.57)$ & $1.3(0.18)$ \\
\hline
\end{tabular}

For flexural strength case, it can be seen from Table 9 that mortar containing 10\%, 15\% and 20\% marble powder did not lose their strength significantly after exposure to $300{ }^{\circ} \mathrm{C}$. Control cement mortar and marble powder mortar with $5 \%$ replacement lost about $6 \%$ flexural strength. When exposure temperature was increased to $600{ }^{\circ} \mathrm{C}$ degree, all mortar lost strength in the order of $50 \%$. However, marble powder containing mortar showed similar performance to control cement mortar at $600{ }^{\circ} \mathrm{C}$. Similarly, at $900{ }^{\circ} \mathrm{C}$ degree, marble powder containing mortar showed similar performance to control cement mortar, however, strength reduction rate was in the order of $80 \%$.

\begin{tabular}{rcccc}
\multicolumn{5}{c}{ Table 10. Compressive test results after high temperature (MPa) (\%) (Yamanel, 2015). } \\
\hline Mix no & $20{ }^{\circ} \mathrm{C}$ & $300{ }^{\circ} \mathrm{C} / 20^{\circ} \mathrm{C}$ & $600{ }^{\circ} \mathrm{C} / 20^{\circ} \mathrm{C}$ & $900{ }^{\circ} \mathrm{C} / 20^{\circ} \mathrm{C}$ \\
\hline M-0 & 52.7 & $54.6(1.04)$ & $31.9(0.61)$ & $18.1(0.34)$ \\
M-5 & 52.1 & $53.7(1.03)$ & $29.9(0.57)$ & $18.6(0.36)$ \\
M-10 & 48.7 & $51.4(1.06)$ & $27.8(0.57)$ & $15.8(0.32)$ \\
M-15 & 46.3 & $49.1(1.06)$ & $28.8(0.62)$ & $16.4(0.35)$ \\
M-20 & 42.8 & $46.7(1.09)$ & $27.2(0.64)$ & $15.5(0.36)$ \\
\hline
\end{tabular}

For compressive strength case, Table 10 exhibited all mortar gained strength after exposure to $300{ }^{\circ} \mathrm{C}$. Strength gain was between $3 \%$ and $9 \%$. Marble powder containing mortar showed similar or better performance to cement mortar performance at $300^{\circ} \mathrm{C}$. As amount of marble powder in mortar was increased, the performance of mortar performance increased at $300{ }^{\circ} \mathrm{C}$ exposures. This increase can be attributed to thermal drying and thermal dehydration of cement paste as reported by Dias, Khoury, \& Sullivan (1990) that compressive strength increase occurs at about $300{ }^{\circ} \mathrm{C}$ due to thermal drying and thermal dehydration of cement paste. When the elevated temperature was increased to $600{ }^{\circ} \mathrm{C}$ and $900{ }^{\circ} \mathrm{C}$ degree, all mortars lost their strength. Reduction rate was in the order of $40 \%$ at $600{ }^{\circ} \mathrm{C}$ degree exposure. It was in the order of $65 \%$ at $900{ }^{\circ} \mathrm{C}$ degree exposure. Comparison between control cement mortar and marble powder containing mortar showed that mortar made with marble powder exhibited similar or better performance than control cement mortar performance.

\section{Drying shrinkage results}

Mortar prepared in this study including marble powder containing mortar and control cement mortar were cured in a curing chamber with $50 \%$ relative humidity at $20^{\circ} \mathrm{C}$ degree as in carbonation part to measure shrinkage values of mortar. Mortar samples with $25 \times 25 \times 285 \mathrm{~mm}$ sized used for shrinkage measurement. After de-moulding shrinkage samples from their cast, first length measurements were taken, then, they were cured in curing chamber. Shrinkage measurements were taken for specific time interval up to 360 days according to ASTM C 596 (ASTM C596, 2010). Shrinkage development of mortars was presented in Figure 5. 


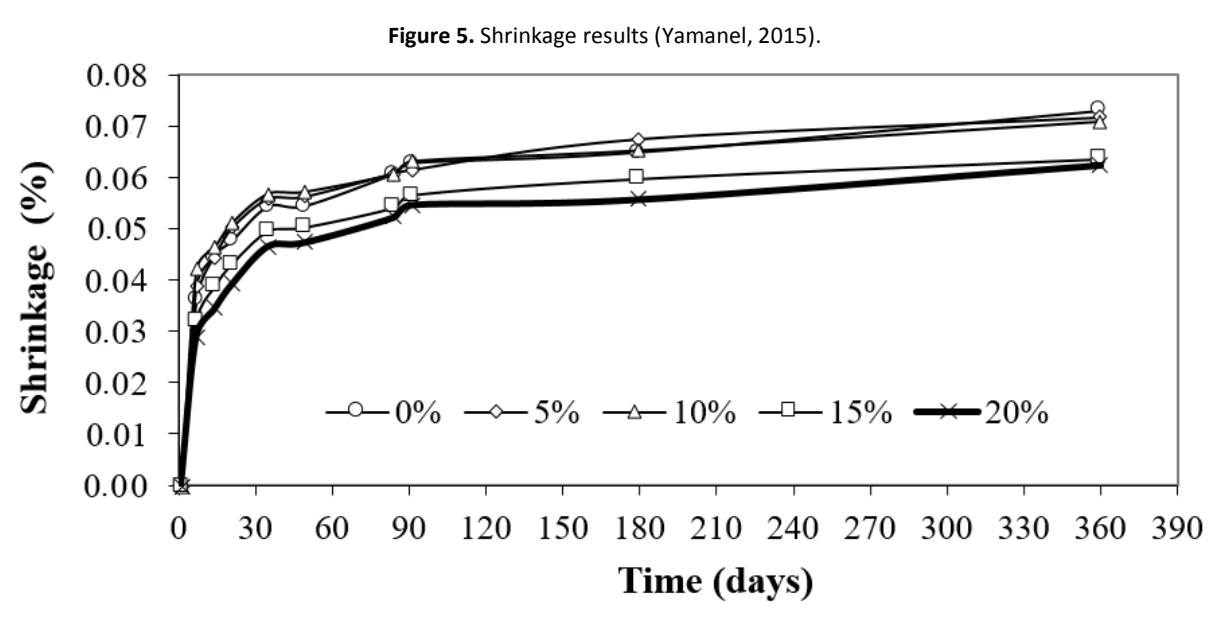

It can be observed from Figure 5 that shrinkages of all mortars were increased with increasing time interval. This is caused by hydration of cement since shrinkage is function of hydration of cement. However, replacing marble powder with cement partially caused a reduction in shrinkage value in comparison to control cement mortar. The higher replacement of marble powder result with higher reduction in shrinkage value causing less shrinkage compared to control cement mortar. This is attributed to reduction of cement content due to partial replacement of marble powder with cement. Shrinkage is known to be a function of hydration of cement, marble powder is known as an inert material. When shrinkage is restraint, it causes internal tensile stress resulting with shrinkage cracks, thus, drying shrinkage reduction property of marble powder is found to be significant and favourable.

Conclusions

- Unit weight of mortar made with inclusion of marble powder was reduced due to difference between specific gravities of cement and marble powder.

- The inclusion of marble powder at all rate in mortar result with better workability. When inclusion of marble powder was $5 \%$ or $10 \%$, the highest influence was observed on workability of mortars.

- Marble powder in mortar results with higher water absorption and porosity values. Higher replacement exhibited higher water absorption and higher porosity at all curing times.

- Mortar containing $5 \%$ or $10 \%$ marble powder showed equivalent or higher compressive strength to cement mortar. When replacement ratios are $15 \%$ and $20 \%$, marble inclusion result with a reduction in compressive strength compared control cement mortar. However, the difference was to diminish with curing time. The same conclusion is valid for flexural strength case.

- Abrasion resistance of mortar made with marble powder was lower than that of control cement mortar.

- Marble powder containing mortar carbonated more than that of cement mortar due to its higher porosity values.

- The inclusion of marble powder in mortar result with a reduction in shrinkage values in comparison to mortar made with cement. The reduction was found to be significant.

- Based on experimental study, it is concluded that marble powder can be utilized as cement replacement in mortar up to $10 \%$.

- Finally, utilization of marble powder as cement replacement may help to reduce $\mathrm{CO}_{2}$ emission to atmosphere by reducing cement quantity in the mixture, thus, it can help to conserve natural resources as well as protect environment.

Alyamac, K. E., Ghafari, E., \& Ince, R. (2017). Development of eco-efficient self-compacting concrete with waste marble powder using the response surface method. Journal of Cleaner Production, 144, 192-202. https://doi.org/10.1016/j.jclepro.2016.12.156

ASTM C 642-13. (2013). Standard Test Method for Density, Absorption, and Voids in Hardened Concrete. American Society for Testing and Material. https://doi.org/10.1520/C0642-13.5.

ASTM C596. (2010). Standard Test Method for Drying Shrinkage of Mortar Containing Hydraulic Cement 1. Annual Book of ASTM Standards (Vol. 11). https://doi.org/10.1520/C0596-09.2

Corinaldesi, V., Moriconi, G., \& Naik, T. R. (2010). Characterization of marble powder for its use in mortar and concrete. Construction and Building Materials, 24(1), 113-117. https://doi.org/10.1016/j.conbuildmat.2009.08.013 
Dias, W. P. S., Khoury, G. A., \& Sullivan, P. J. E. (1990). Mechanical properties of hardened cement paste exposed to temperatures up to 700 C (1292 F). ACl Materials Journal.

Ergün, A. (2011). Effects of the usage of diatomite and waste marble powder as partial replacement of cement on the mechanical properties of concrete. Construction and Building Materials, 25(2), 806-812. https://doi.org/10.1016/j.conbuildmat.2010.07.002

Hebhoub, H., Aoun, H., Belachia, M., Houari, H., \& Ghorbel, E. (2011). Use of waste marble aggregates in concrete. Construction and Building Materials 25(3), 1167-1171. https://doi.org/10.1016/j.conbuildmat.2010.09.037

Kabeer, K. I. S. A., \& Vyas, A. K. (2018). Utilization of marble powder as fine aggregate in mortar mixes. Construction and Building Materials, 165, 321332. https://doi.org/10.1016/j.conbuildmat.2018.01.061

Khyaliya, R. K., Kabeer, K. I. S. A., \& Vyas, A. K. (2017). Evaluation of strength and durability of lean mortar mixes containing marble waste. Construction and Building Materials, 147, 598-607. https://doi.org/10.1016/j.conbuildmat.2017.04.199

Koçyiğit, Ş. (2016). Pumice aggregates of marble dust and analysis of waste tragacant mixed cement based composite material properties of engineering. Graduate School of Natural and Applied Sciences, Fırat University, PhD Thesis.

Singh, M., Srivastava, A., \& Bhunia, D. (2017). An investigation on effect of partial replacement of cement by waste marble slurry. Construction and Building Materials, 134, 471-488. https://doi.org/10.1016/j.conbuildmat.2016.12.155

Talah, A., Kharchi, F., \& Chaid, R. (2015). Influence of Marble Powder on High Performance Concrete Behavior. Procedia Engineering, 114, 685-690. https://doi.org/10.1016/j.proeng.2015.08.010

Tekin, I. (2016). Properties of $\mathrm{NaOH}$ activated geopolymer with marble, travertine and volcanic tuff wastes. Construction and Building Materials, 127, 607-617. https://doi.org/10.1016/j.conbuildmat.2016.10.038

Toubal Seghir, N., Mellas, M., Sadowski, Ł., \& Żak, A. (2018). Effects of marble powder on the properties of the air-cured blended cement paste. Journal of Cleaner Production, 183, 858-868. https://doi.org/10.1016/j.jclepro.2018.01.267

TS 2824 EN 1338. (2005). Concrete paving blocks-Requirements and test methods. Turkish Standart, Ankara.

TS EN 1015-11. (2000). Mortar Testing Method, Part 11. Measurement of Compressive and Flexural Tensile Strength of Mortar. Turkish Standart, Ankara.

TS EN 1015-3. (2000). Methods of test for mortar for masonry: Part 3. Determination of consistence of fresh mortar (by flow table). Turkish Standart, Ankara.

Uysal, M., Akyuncu, V., Tanyildizi, H., Sumer, M., \& Yildirim, H. (2018). Optimization of durability properties of concrete containing fly ash using T aguchi 's approach and Anova analysis, 364-382. https://doi.org/10.7764/RDLC.17.3.364

Vardhan, K., Goyal, S., Siddique, R., \& Singh, M. (2015). Mechanical properties and microstructural analysis of cement mortar incorporating marble powder as partial replacement of cement. Construction and Building Materials, 96, 615-621. https://doi.org/10.1016/j.conbuildmat.2015.08.071

Yamanel, K. (2015). Investigation of Kayseri area properties of waste marble powder mortar. Graduate School of Natural and Applied Sciences, Erciyes University, MSc Thesis. 